\title{
Synthesis and characterization of poly(o-toluidine)/kaolinite conductive composites for humidity and temperature sensing
}

\author{
Nem ve sıcaklık algılama için iletken poli(o-toluidin)/kaolinit \\ kompozitlerinin sentezi ve karakterizasyonu
}

\author{
Filiz BORAN ${ }^{*}$ iD , Sevil ÇETINKKAYA ${ }^{2}$ iD , Meral KARAKIŞLA ${ }^{3}$ iD , Mehmet SAÇAK ${ }^{4}$ iD \\ 1Department of Chemical Engineering, Engineering Faculty, Hitit University, Çorum, Turkey. \\ filizbektas@hitit.edu.tr \\ ${ }^{2}$ Department of Chemical Engineering, Engineering Faculty, Cumhuriyet University, Sivas, Turkey. \\ scetin@cumhuriyet.edu.tr \\ 3,4Department of Chemistry, Faculty of Science, Ankara University, Ankara, Turkey \\ karakis@science.ankara.edu.tr, sacak@science.anakara.edu.tr
}

Received/Geliş Tarihi: 07.12.2016, Accepted/Kabul Tarihi: 29.09.2017

doi: $10.5505 /$ pajes.2017.94557

* Corresponding author/Yazıșılan Yazar Research Article/Arastırma Makalesi

\begin{abstract}
Conductive poly(o-toluidine)/kaolinite composite was synthesized via chemical polymerization of o-toluidine in the availability of kaolinite using ammonium persulfate as oxidizing agent. To investigate the use of the prepared conductive composite as humidity and temperature sensor, the effect of polymerization conditions such as $\mathrm{HCl}$, o-toluidine and oxidant concentrations on the amount of conductive POT contained in the composite and the conductivity values of composites were investigated. It was found that the composites with the highest poly (otoluidine) content (29.4\%) and conductivity $\left(8.3 \times 10-4 \mathrm{Scm}^{-1}\right)$ were obtained by $0.2 \mathrm{M}$ ammonium persulfate, $0.4 \mathrm{M}$ o-toluidine and $1 \mathrm{M}$ hydrochloric acid for 2 hours of continuous polymerization at $20^{\circ} \mathrm{C}$. The resistivity values of pure poly(o-toluidine) and poly (o-toluidine)/kaolinite composite were monitored during heatingcooling cycles in the range of $0-100{ }^{\circ} \mathrm{C}$. Changes in resistivity for pure poly(o-toluidine) and poly(o-toluidine)/kaolinite composite with humidity 30-90\% were examined and humidity sensor behavior was determined. Characterization of the prepared composite was performed by Fourier transform infrared spectroscopy (FT-IR), X-ray diffraction $(X R D)$, thermogravimetric analysis (TGA) and scanning electron microscopy techniques (SEM).
\end{abstract}

Keywords: Poly(o-toluidine), Kaolinite, Composite, Conductive polymer, Temperature sensor, Humidity sensor

\section{Introduction}

Conductive polymer composites (CPC) are typically prepared using various conducting polymers with layered inorganic materials or nanostructures of metal oxides and inorganic materials by chemical [1],[2] and electrochemical methods [3]. They have great significance in various areas such as physics, electronics, and biosensor [4] because the mechanical, thermal and physicochemical properties of polymer composites including inorganic materials are enhanced as compared to pure materials [5]-[7].

In recent years, conductive polymers attracted special attention in creating semi-conductors because of their redox behaviors, electronic properties, morphological varieties in nanometer scale and easy synthesis [8],[9]. Because of good redox behaviors, modified conductive polymers that have hydrophilic properties are reported to be used in constructing humidity sensors [2],[10]. The groups of $\left(-\mathrm{CH}_{3},-\mathrm{OCH}_{3},-\mathrm{OC}_{2} \mathrm{H}_{5}\right)$ that are added to Polyaniline (PAn)'s chain decrease the conductivity,
Öz

Iletken poli(o-toluidin)/kaolinit kompoziti, kaolinit varlığında yükseltgen olarak amonyum persülfat kullanilarak o-toluidinin kimyasal polimerizasyonu ile hazırlandı. Hazırlanan iletken kompozitin nem ve sıcaklık algılayıcısı olarak kullanımını araștırabilmek için kompozitin içerdiği iletken POT miktarı ve kompozitin iletkenlik değerlerine polimerizasyon koșullarından $\mathrm{HCl}$, o-toluidin ve yükseltgen madde derişimlerinin etkisi incelendi. En yüksek poli(o-toluidin) miktarı (\%29.4) ve iletkenliğe sahip $\left(8.3 \times 10^{-4} \mathrm{Scm}^{-1}\right)$ kompozitin $0.2 \mathrm{M}$ amonyum persülfat, $0.4 \mathrm{M}$ o-toluidin ve $1.0 \mathrm{M}$ hidroklorik asit kullanılarak $20^{\circ} \mathrm{C}$ sıcaklıkta ve 2 sa. sürdürülen polimerizasyon ile elde edildiği bulundu. Saf poli(o-toluidin) ve poli(o-toluidin)/kaolinit kompozitinin direnç değerleri $0-100{ }^{\circ} \mathrm{C}$ sıcaklık aralığında tekrar edilen ısıtma-soğutma ișlemleri sirasında izlenerek sıcaklığa karșı duyarlılı̆̆ incelendi. Bağıl nem oranı \%30-90 arasında değiștirilen ortamlarda saf poli(o-toluidin) ve kompozitin direnç değerleri ölçülerek nem sensör davranışı belirlendi. Hazırlanan kompozitin karakterizasyonu Fourier dönüșümlü kızılötesi spektroskopisi (FT-IR), X-Ișınları kırınımı (XRD) termogravimetrik analiz (TGA) ve taramalı elektron mikroskobu (SEM) teknikleri ile yapılds.

Anahtar kelimeler: Poli(o-toluidin), Kaolinit, Kompozit, İletken polimer, Sıcaklık sensör, Nem sensör

but they increase the processibility of polymers due to increasing of solubility of polymer in organic solvents [11]. Among them poly(o-toluidine) (POT) was widely used because of its environmental friendly conditions [12],[13].

Clay is the most preferred non-conductive material in preparing composites among other minerals due to their large surface areas, high ionization capacities, abundant existences and being cheap [1],[14]-[16]. In addition, they are also used to enhance the thermal stability of composites [17]. Kaolinite (1:1) is a two-layered clay mineral, has dioctahedral aluminosilicate $\left(\mathrm{Al}_{2} \mathrm{Si}_{2} \mathrm{O}_{5}(\mathrm{OH})_{4}\right)$ and found in large quantities in nature. The force holding kaolinite layers together is hydrogen bond that forms between tetrahedral oxygen atoms and octahedral hydroxyl ions on the surface [18]. There is limited research related with the use of kaolinite on preparation of conducting polymer-clay composites [14],[15],[17],[19]-[21].

In this study, conductive POT/kaolinite composite (PKC) was synthesized through in situ chemical polymerization of 0 - 
toluidine by adding kaolinite. The effects of $\mathrm{HCI}$ that is preferred as dopant, the concentrations of o-toluidine and oxidant on conductivity and the POT content of prepared PKC were investigated. The capacities of PKC as humidity and temperature sensors were followed by monitoring electrical resistivity of $\mathrm{POT}$ and $\mathrm{PKC}$ within ambient temperature and relative humidity $(\mathrm{RH})$.

\section{Materials and methods}

\section{$2.1 \quad$ Materials}

Kaolinite with particle size smaller than $63 \mu \mathrm{m}$ and chemical composition of $62.19 \% \mathrm{SiO}_{2}, 26.18 \% \mathrm{Al}_{2} \mathrm{O}_{3}, 0.37 \% \mathrm{Fe}_{2} \mathrm{O}_{3}, 0.38 \%$ $\mathrm{TiO}_{2}, 0.17 \% \mathrm{CaO}, 0.13 \% \mathrm{MgO}, 0.20 \% \mathrm{Na}_{2} \mathrm{O}, 0.14 \% \mathrm{~K}_{2} \mathrm{O}$ and $0.10 \% \quad \mathrm{SO}_{3}$ was received (Esan/Eczacıbası, Turkey). Hydrochloric acid (HCI, 37\%), ammonium persulfate (APS 98\%) and o-toluidine (99.5\%) were used as supplied from Merck.

\subsection{Material preparation}

After $1 \mathrm{~g}$ of kaolinite was put into a glass tube, a suitable concentration of acid solutions was added into the tube and mixed about $10 \mathrm{~min}$. Then, o-toluidine monomer was added into the above solution. Polymerization was carried out by dropwise addition of an appropriate concentration of oxidant. Dark green precipitate thus formed was separated by centrifugation and washed with deionized water and methyl alcohol to take oxidant and unreacted o-toluidine away, respectively. It was then washed with dilute acid solution to recover dopant which was taken away from the structure by washing process. After drying the synthesized product at $50{ }^{\circ} \mathrm{C}$ for $24 \mathrm{~h}$ under vacuum, the POT content in the PKC was defined as shown in Eq. (1):

$$
\operatorname{POT}(\%)=\frac{(W-W o)}{W o} \times 100
$$

Where $W$ and $W o$ are the weight of as-synthesized product and kaolinite, respectively.

\section{$2.3 \quad$ Measurements}

Powder products were pelletized to a diameter of $1.3 \mathrm{~cm}$ by keeping under a vacuum press at $80 \mathrm{kN}$ for $5 \mathrm{~min}$. The resistivity of PKC was performed using two probe methods with a Thurlby electrometer in ambient temperature [15]. Conductivity values of products were defined from the measured resistivity data.

The powder X-ray diffraction was carried out (XRD, Rigaku DMAX IIIC, METU Central LAB., Ankara, Turkey) using CuK $\alpha$ radiation at a speed of $2^{\circ} \mathrm{min}^{-1}$.

Thermogravimetric analysis (TGA) of products was carried out on Shimadzu TA50 instrument (Cumhuriyet University, Sivas, Turkey) at a heating rate of $10{ }^{\circ} \mathrm{Cmin}^{-1}$ under a nitrogen atmosphere over a temperature range of $30-900{ }^{\circ} \mathrm{C}$. Samples were characterized by Fourier Transform Infrared Spectrum (FT-IR) between the spectral range from 4000 to $400 \mathrm{~cm}^{-1}$ using $\mathrm{KBr}$ pellets with 1:100 (wt\%) sample concentration ratio by a Mattson 1000 model FT-IR spectrometer (Cumhuriyet University, Sivas, Turkey). The morphology of the synthesized product coated with gold was observed by scanning electron microscopy techniques (SEM, JEOL JSM 6060 LV, METU Central LAB., Ankara, Turkey).

After the sample formed as disk was engaged by copper wires using a conductive clip put into a glass closed test chamber with two necks. The electrical resistivity of the synthesized product was performed by changing the temperature from $0{ }^{\circ} \mathrm{C}$ to 100 ${ }^{\circ} \mathrm{C}$ with $2{ }^{\circ} \mathrm{C}$ increments [17].

After the synthesized products were prepared as pellet, it was put into an humidity system consists of $500 \mathrm{~mL}$ two-neck round-bottom flask as previously described [22] and the resistivity of the sample was measured under changing ambient RH. The RH in the glass (\%) was computed by changing ice-water mixture temperature from $0{ }^{\circ} \mathrm{C}$ to ambient value. The humidity in the flask was defined as the ratio of the water vapor pressure $(E w)$ at $T 1$ (temperature of water in the flask) to that at $T 2$ (temperature of sample) according to eq.2

$$
R H(\%)=\frac{E w(T 1)}{E w(T 2)} \times 100
$$

Values for the saturated vapor pressure of water were obtained from the Chemical Engineers' Handbook [23].

\section{$2.4 \quad$ Results and discussions}

\subsubsection{Influence of the HCI concentration}

Figure 1 shows the POT content and conductivity for PKC synthesized at varying HCI concentrations between 0.1 and 2 $\mathrm{M}$. It was observed that, as HCI concentrations increased from $0.1 \mathrm{M}$ to $1.0 \mathrm{M}$, POT content of PKC increased until 0.5 M HCI concentration. However, POT content of PKC decreased after 0.5 M HCI concentration. The conductivity of PKC reached its highest value at $1.0 \mathrm{M} \mathrm{HCI}$ concentration $\left(10.8 \times 10^{-5}\right)$ and decreased at the higher concentrations than $1.0 \mathrm{M}$.

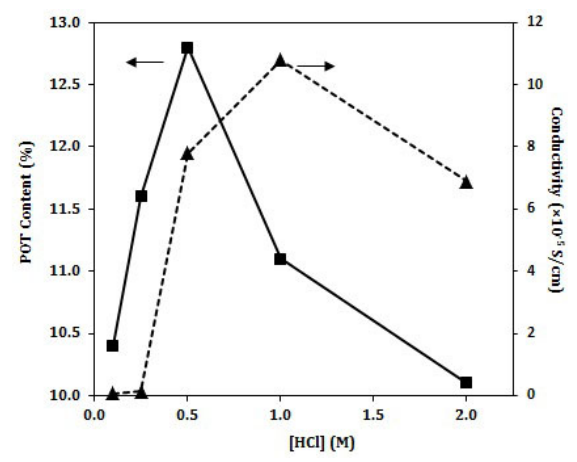

Figure 1: The influence of HCI concentration on ( $\mathbf{m})$ POT content and ( $\boldsymbol{\Delta}$ ) Conductivity of PKC ([APS]: $0.07 \mathrm{M}$, [otoluidine]: $0.1 \mathrm{M}$, polymerization time: $2 \mathrm{~h}$, temperature: $20^{\circ} \mathrm{C}$ ).

Oxidative polymerization of aniline and its derivatives have similar polymerizations mechanism. Therefore, the decrease in conductivity and POT content of PKC above a particular acid concentration can be clarified by taking the polymerization mechanism of o-toluidine. While o-toluidine rings are bonding to each other, $\mathrm{H}^{+}$ions are drop out of the structure throughout the polymerization. Since defection of $\mathrm{H}^{+}$ions is hard to achieve at lower $\mathrm{pH}$, chain growth is foiled. In addition, short or soluble POT chains are occurred by increasing acid concentration. As a result of the two effects given above, while POT content decreases due to soluble POT chains forming on kaolinite surfaces, the conductivity decreases due to short conjugation [14].

\subsubsection{Influence of the o-toluidine concentration}

The influence of the o-toluidine concentration on the POT content and conductivity of PKC was examined in the range of 
o-toluidine concentration changing from $0.05 \mathrm{M}$ to $0.6 \mathrm{M}$ (Figure 2). As shown Figure 2, while POT content of PKC increased continuously with o-toluidine concentration, the conductivity of PKC increased until $0.4 \mathrm{M}$ and then decreased at higher monomer concentrations. This decrease indicates the formation of shorter POT chains on kaolinite particles with increasing monomer concentration [17].

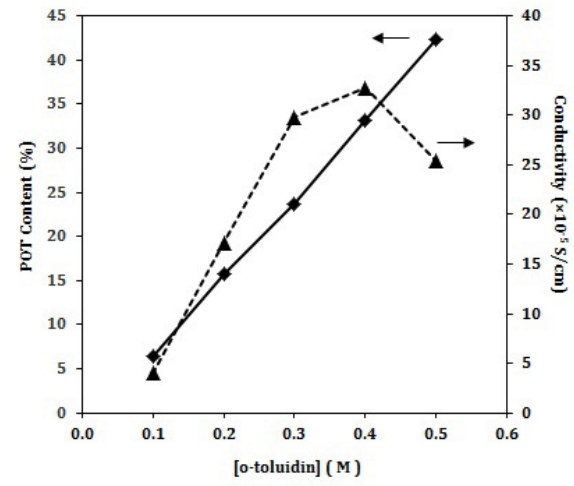

Figure 2: The effect of o-toluidine concentration on ( $\mathbf{\square})$ POT content and ( $\mathbf{\Delta}$ ) Conductivity of PKC ([APS]: $0.07 \mathrm{M}$, [HCI]:

$1.0 \mathrm{M}$, polymerization time: $2 \mathrm{~h}$, temperature: $20^{\circ} \mathrm{C}$ ).

\subsubsection{Influence of the oxidizing agent concentration}

The influence of concentration of APS used as oxidizing agent on the POT content and the conductivity of PKC are shown in Figure 3.

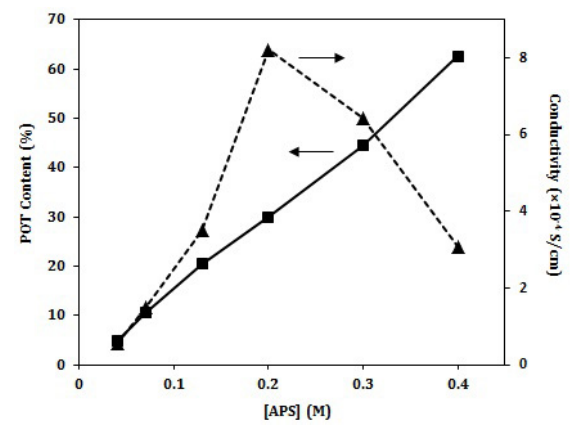

Figure 3: The influence of APS concentration on ( $\square$ ) POT content and $(\boldsymbol{\Delta})$ Conductivity of PKC ([o-toluidine]: 0.4 M, [HCI]: $1.0 \mathrm{M}$, polymerization time: $2 \mathrm{~h}$, temperature: $20^{\circ} \mathrm{C}$ ).

The Figure 3 shows that both the POT content and conductivity of the PKC are related to the oxidizing agent concentration. While the POT content of PKC increased as APS concentration increased, the conductivity of PKC increased until $0.2 \mathrm{M}$ and then sharply decreased. This sharp decrease in conductivity can be explained by the interruption off conjugation of radical cations forming over POT chains [24].

By varying reaction parameters, the conductivity of the PKC changed between the values of $8.2 \times 10^{-4} \mathrm{Scm}^{-1}$ and $10.8 \times 10^{-5}$ $\mathrm{Scm}^{-1}$. It was also observed that the conductivity of our PKC samples was to be lower than that the conducting polymer of bare POT $\left(4.5 \times 10^{-4} \mathrm{Scm}^{-1}\right)$ synthesized at the similar conditions due to the addition of kaolinite as an insulating material to composite.

According to these results, a feasible reaction parameters for highest POT content and conductivity of the composite have been found as $0.2 \mathrm{M}$ APS, $0.4 \mathrm{M}$ o-toluidine, $1 \mathrm{M} \mathrm{HCI}$ for $2 \mathrm{~h}$ reaction time at $20{ }^{\circ} \mathrm{C}$ reaction temperature. Since the maximum conductivity value of the composite reached to the about $30 \%$ POT content, the sample containing 29.4\% POT was preferred in characterization and thermal and humidity sensing studies.

\subsubsection{FT-IR}

FT-IR spectra of kaolinite, POT and PKC including 29.4\% POT are given in Figure 4.

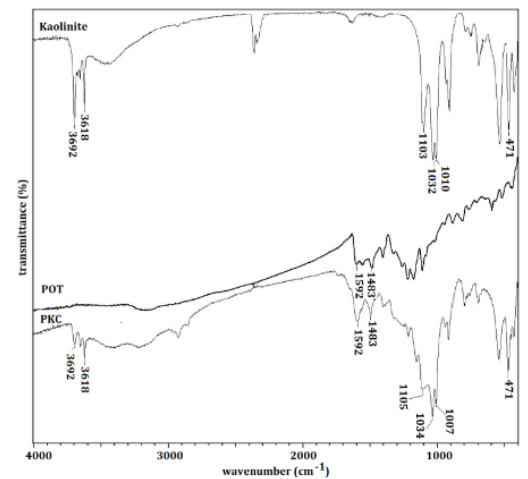

Figure 4: FT-IR spectra for kaolinite, POT and PKC containing $29.4 \%$ POT

The bands for quinoid and benzenoid rings observed at 1592 and $1483 \mathrm{~cm}^{-1}$ in the spectrum of PKC are assigning for C-N stretching vibrations in POT, respectively [25]. Other peaks observed between $1000-1100 \mathrm{~cm}^{-1}$ and at $471 \mathrm{~cm}^{-1}$ are related to Si-O stretching vibrations of kaolinite. While the band observed at $3618 \mathrm{~cm}^{-1}$ can be corresponded to inner hydroxyl groups lying between tetrahedral and octahedral sheets, the peaks around $3692 \mathrm{~cm}^{-1}$ was ascribed to the symmetric stretching vibration of hydroxyl groups at the surface of octahedral sheets [14].

\subsubsection{XRD}

Figure 5 shows the $X$-ray diffraction data for kaolinite, POT and

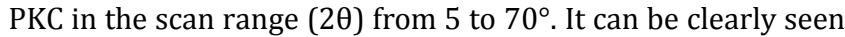
that the diffraction peaks at 2 theta $\left(12.4^{\circ}\right)$ which belong to characteristic of kaolinite are well distinct and sharp in Figure 5a [19].

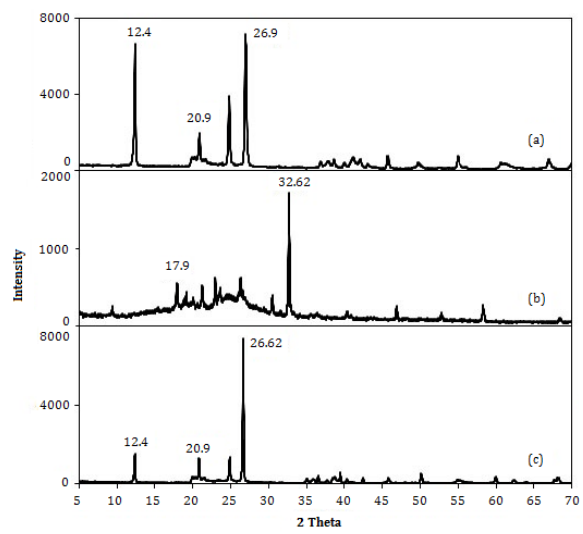

Figure 5: X-ray diffraction pattern for; (a): Kaolinite, (b): POT and (c): PKC including 29.4\% POT.

In addition to the existence of amorphous regions in the POT spectrum in the range of $15-30^{\circ}$ in the POT spectrum, crystal regions are also noticed. It is observed that the basal peak of kaolinite does not exhibit any change that POT does not enlarge an interlayer distance between the plates of kaolinite. The decrease in the intensity of the basal peak of kaolinite in the 
PKC can be relative to the low scattering owing to the formation of POT on the kaolinite surface [15].

\subsubsection{TGA}

The thermal stability of kaolinite, POT and PKC including 29.4\% POT was evaluated by thermogravimetric analysis (Figure 6).

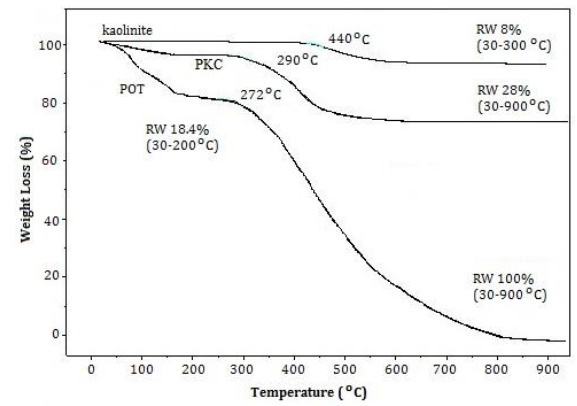

Figure 6: TGA curves of kaolinite, POT and PKC including

$$
29.4 \% \text { POT. }
$$

As seen from the Figure 6, kaolinite started to lose its weight at $440{ }^{\circ} \mathrm{C}$ and lost only $8 \%$ its weight when temperature reached $900{ }^{\circ} \mathrm{C}$. Weight loss of $18.4 \%$ of POT was observed between 100 ${ }^{\circ} \mathrm{C}$ and $272{ }^{\circ} \mathrm{C}$ due to the loss of volatile compounds such as water molecules and dopant anions. As the decomposition of POT backbone was noticed at $272{ }^{\circ} \mathrm{C}$, its total weight was found to be retained at $900{ }^{\circ} \mathrm{C}$. It was observed that PKC showed thermal behavior between its components as it loses $28 \%$ of its weight up to $900^{\circ} \mathrm{C}$. Also the decomposition temperature of the $\mathrm{PKC}$ is $290^{\circ} \mathrm{C}$. Hence, it can be concluded that the PKC has better thermal stability than POT.

\subsubsection{SEM}

The SEM micrographs of PKC and its components are given in Figure 7. It can be seen from Figure 7a that kaolinite included little sheets with disordered sides. POT was also morphology of large, shapeless, varying grain size and sponge-like (Figure 7b). This sharp and plane appearance of kaolinite was disappeared while plate form is retained in the PKC structure. It was also noticed that the particle size of POT got smaller and appeared to cluster the plates.

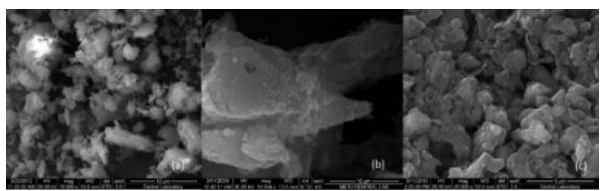

Figure 7: SEM micrographs of (a): Kaolinite, (b): POT and (c): PKC including 29.4\% POT.

\subsubsection{Thermal and humidity sensing}

The temperature sensing property of POT and PKC containing $29.4 \%$ POT was examined by monitoring their electrical resistivity throughout four repetitive heating-cooling cycles in the temperature range from 0 to $100{ }^{\circ} \mathrm{C}$ (Figure 8).

As shown in the Figure 8a, the resistivity of POT decreased during heating process up to $100{ }^{\circ} \mathrm{C}$ and reached its minimum value at $100{ }^{\circ} \mathrm{C}$. On the other hand, the resistivity increased during cooling process down to $0{ }^{\circ} \mathrm{C}$ reached its maximum value at $0{ }^{\circ} \mathrm{C}$. The similar trend was observed at repeated cycles. Resistivity values of POT stabilized after the last three cycles and the about same values were recorded at $100{ }^{\circ} \mathrm{C}$ and $0^{\circ} \mathrm{C}$.

The similar change during heating-cooling processes was also observed for PKC. However, the increasing and the decreasing of the resistivity showed two stage changes. This change regularly repeated itself after the first cycle. In addition, the resistivity values of PKC were getting stable faster than that of POT at repeated cycles. These data indicated that PKC has better temperature sensing properties than POT for the temperature range tested.

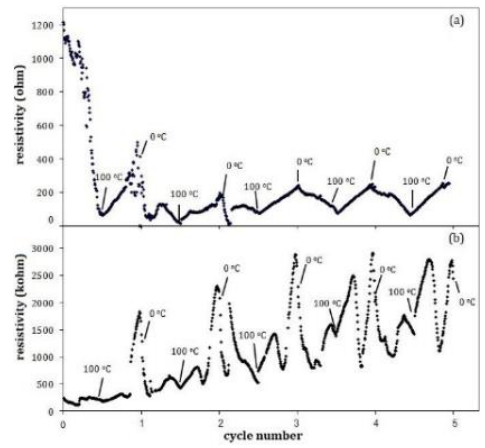

Figure 8: Variation of resistivity throughout heating-cooling system in the range $0-100^{\circ} \mathrm{C}$ for (a): POT and (b): PKC including 29.4\% POT.

The variations in resistivity values of POT and PKC with RH in the range of $30-90 \%$ are given in Figure 9 and 10, respectively. The resistivity of both samples decreased with increasing humidity. After the RH reached to $90 \%$ in the glass cell, the sample was removed and put into the glass cell containing phosphorus pentoxide, and was hold in it until its resistivity stabilized. In repeated expose to humidity-drying processes, the resistivity of POT reached the initial resistivity value of cycle after second drying process.

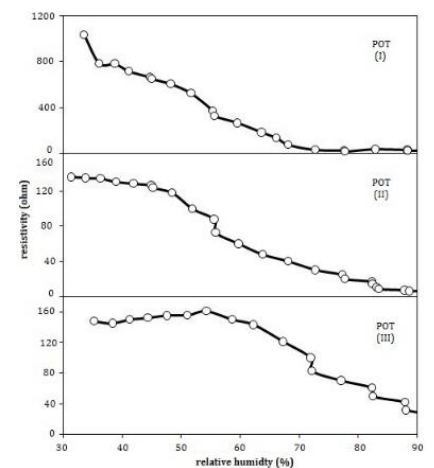

Figure 9: Variation of resistivity for POT in 30-90\% humidity range during humidify-drying processes repeated three times.

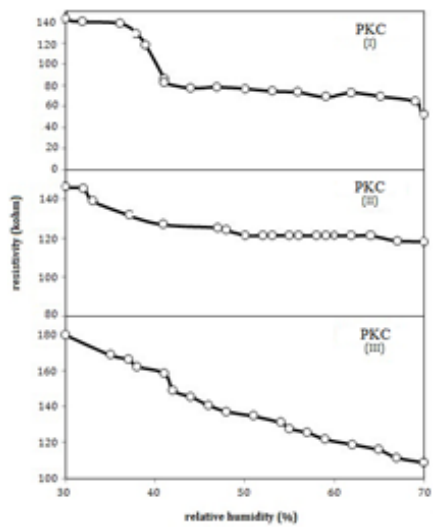

Figure 10: Variation of resistivity for PKC including 29.4\% POT in $30-70 \%$ humidity range during humidify-drying processes repeated three times. 
The resistivity of PKC showed a sudden decrease initially until about $40 \% \mathrm{RH}$ and then decreased steadily with increasing humidity compared to the behavior of POT. Although the PKC was kept on phosphorus pentoxide, it could not reach its initial resistivity value recorded in a previous stage.

The resistance decreases with an increase in RH may be attributed to increasing the mobility of dopant anions bound weakly to the POT chains via Van der Waals forces [2]. In addition to this explanation, POT chains absorb water molecules and swell with increasing $\mathrm{RH}$, and convert into a straight chain conformation. At low RH, POT chains are generally in compact coiled structure which has the influence of decreasing resistivity.

\section{Conclusion}

In this study, it was observed that the conductivity and POT content of PKC varied by experimental conditions of polymerization. The conductivity of PKC enhanced as $8.3 \times 10^{-4}$ $\mathrm{Scm}^{-1}$ using $0.4 \mathrm{M}$ o-toluidine, $0.2 \mathrm{M} \mathrm{APS}$ and $1.0 \mathrm{M} \mathrm{HCI}$ According to XRD and SEM results, polymerization of otoluidine was also observed on kaolinite particles as well as inside of kaolinite plates. PKC had more thermal stability than POT.

The resistance evaluations retrieved throughout repetitive heating-cooling cycles indicated that the PKC had more sensitivity than that of POT, and therefore can be used as a sensor. It can be stated that pure POT can become stable by humidifying \& drying process as the PKC becomes stable at later stages of drying process although it is more sensitivity the humidity.

\section{Acknowledgement}

This work was supported by Turkish Scientific and Technical Research Organization (TUBITAK) project numbered as 107 M542.

\section{References}

[1] Elbokl TA, Detellier C. "Aluminosilicate nanohybrid materials. Intercalation of polystyrene in kaolinite". Journal of Physics and Chemistry of Solids, 67(5-6), 950955, 2006.

[2] Singla ML, Awasthi S, Srivastava A. "Humidity sensing; using polyaniline $/ \mathrm{Mn}_{3} \mathrm{O}_{4}$ composite doped with organic/inorganic acids". Sensors and Actuators B, 127, 580-585, 2007.

[3] Hyun JE, Lee PC, Tatsumi I. "Preparation and electrochemical properties of sulfur-polypyrrole composite cathodes for electric vehicle applications". Electrochimica Acta, 176, 887-892, 2015.

[4] AL-Oqla MF, Sapuan SM, Anwer T, Jawaid M, Hoque ME. "Natural fiber reinforced conductive polymer composites as functional materials: A review". Synthetic Metals, 206, 42-54, 2015.

[5] Kim SY, Noh YJ, Yu J. "Improved thermal conductivity of polymeric composites fabricated by solvent-free processing for the enhanced dispersion of nanofillers and a theoretical approach for composites containing multiple heterogeneities and geometrized nanofillers". Composites Science and Technology, 101, 79-85, 2014.

[6] Guo C, Duan H, Dong C, Zhao G, Liu Y, Yang Y. "Preparation of the polypropylene/nickel coated glass fibers conductive composites with a low percolation threshold". Materials Letters, 143, 124-127, 2015.
[7] Na-Meng, Zhou N-L. "Blood compatible heparinbenzalkonium modified montmorillonite/PDMS composites". Applied Clay Science, 70, 22-27, 2012.

[8] Mohsennia M, Bidgoli MM, Boroumand FA, Nia AM. "Electrically conductive polyaniline as hole-injection layer for MEH-PPV:BT based polymer light emitting diodes". Materials Science and Engineering B, 197, 25-30, 2015.

[9] Oraon R, Adhikari A, Tiwari SK, Sahu TS, Nayak GC. "Fabrication of nanoclay based graphene/polypyrrole nanocomposite: An efficient ternary electrode material for high performance supercapacitor". Applied Clay Science, 118, 231-238, 2015.

[10] Adhikari B, Majumdar S. "Polymers in sensor applications". Progress in. Polymer. Science, 29, 699-766, 2004.

[11] Mallick K, Witcomb MJ, Scurrell MS. "In situ synthesis of copper nanoparticles and poly(o-toluidine): A metalpolymer composite material". European Polymer Journal, 42, 670-675, 2006.

[12] Borole DD, Kapadi UR, Mahulikar PP, Hundiwale DG. "Electrochemical synthesis and characterization of conducting copolymer: Poly(o-aniline-co-o-toluidine)". Materials Letters, 60, 2447-2452, 2006.

[13] Bilal S, Shah A-HA, Holze R. "A correlation of electrochemical and spectroelectrochemical properties of poly(o-toluidine)". Electrochimica Acta, 54, 4851-4856, 2009.

[14] Acar H, Karakisla M, Sacak M. "Preparation and characterization of conductive polypyrrole/kaolinite composites". Material Science in Semiconductor Processing, 16, 845-850, 2013.

[15] Anakli D, Cetinkaya S. "Preparation of poly(2-ethyl aniline)/kaolinite composite materilas and investigation of their properties". Current Applied Physics, 10, 401-406, 2010.

[16] Erol O, Karakisla M, Unal HI, Saçak M. “Electrorheological properties of polyaniline/K-feldspar conducting composite". Journal of Composite Materials, 46(11), 1295-1304, 2011.

[17] Duran NG, Karakısla M, Aksu L, Saçak M. "Conducting polyaniline/kaolinite composite: Synthesis, characterization and temperature sensing properties". Materials Chemistry and Physics, 118, 93-98, 2009.

[18] Ke YC, Stroeve P. Polymer-Layered Silicate and Silica Nanocomosites. $1^{\text {th }}$ ed. Netherlands, Elsevier, 2005.

[19] Gardolinski JE, Carrera LCM, Cantao MP,Wypych F. "Layered polymer-kaolinite nanocomposites". Journal of Materials Science, 35, 3113-3119, 2000.

[20] Wang YL, Lee BS, Chang KC, Chiu HC, Lin FH, Lin CP. "Characterization, fluoride release and recharge properties of polymer-kaolinite nanocomposite resins". Composites Science and Technology, 67, 3409-3416, 2007.

[21] Sun D, Li Y, Zhang B, Pan X. "Preparation and characterization of novel nanocomposites based on polyacrylonitrile/kaolinite". Composites Science and Technology, 70, 981-988, 2010.

[22] Kulkarni MV, Viswanath AK. "Spectroscopic, thermal and electrical properties of sulphonic acids doped poly (o-anisidine) and their application as humidity sensor". Sensors and Actuators B, 107, 791-797, 2005.

[23] Perry RH, Green DW. Perry's Chemical Engineers' Handbook. $7^{\text {th }}$ ed. The United States of America, McGrawHill, 1999. 
[24] Saravanan C, Shekhar RC, Palaniappan S. "Synthesis of polypyrrole using benzoyl peroxide as a novel oxidizing agent". Macromolecular Chemistry and Physics, 207, 342348, 2006.
[25] Chen K, Li L, Tong G, Qiao R, Hao B, Liang X. "Fabrication and absorbing property of microwave absorbers based on BaAl2Fe10019 and poly(o-toluidine)". Synthetic Metals, 161, 2192-2198, 2011. 